\title{
Integration of Stalk Destruction Methods for the Glyphosate Herbicide-Resistant Cotton
}

\author{
Valdinei Sofiatti (Corresponding Author) \\ Researcher Embrapa Algodão \\ Palmas, Tocantins, Brazil. Postal code: 77001-048 \\ Tel: 55-63-9847496111_E-mail: valdinei.sofiatti@embrapa.br \\ Odilon RRF Silva \\ Researcher Embrapa Algodão \\ Campina Grande, Paraíba, Brazil. Postal code: 58428-095 \\ Tel: 55-83-999809981Ｅ-mail: odilon.silva@embrapa.br
}

Edson R Andrade Junior

Researcher Instituto Matogrossensse do Algodão

Primavera do Leste, Mato Grosso, Brazil. Postal code: 78850-000

Tel: 55-66-996178403Ｅ-mail: edsonjunior@imamt.org.br

\author{
Alexandre CB Ferreira \\ Researcher Embrapa Algodão \\ Goiânia, Goiás, Brazil. Postal code: 75375-000 \\ Tel: 55-62-991471286Ｅ-mail: alexandre-cunha.ferreira@embrapa.br \\ Fabiano J Perina \\ Analyst Embrapa Algodão \\ Luís Eduardo Magalhães, Bahia, Brazil. Postal code: 47850-000 \\ Tel: 55-77-999563355Ｅ-mail: fabiano.perina@embrapa.br
}


Julio C Bogiani

Researcher Embrapa Territorial

Campinas, São Paulo, Brazil. Postal code: 13070-115

Tel: 55-19-984430453 E-mail: julio.bogiani@embrapa.br

Received: December 9, 2021 Accepted: January 10, 2022 Published: January 15, 2022

doi:10.5296/jas.v10i2.19307

URL: https://doi.org/10.5296/jas.v10i2.19307

\begin{abstract}
The increase in geographical areas used for cultivation of transgenic glyphosate herbicide-resistant cotton has hindered the stalk destruction, compromised the phytosanitary break implementation and consequently increased the population of insect pests and cotton plant pathogens. This study evaluated the efficiency of the combining mechanical and chemical methods in the destruction of transgenic cotton stalk resistant to the glyphosate herbicide. Two experiments were carried out in 2015 and 2016 in Primavera do Leste, Mato Grosso, Brazil and Luís Eduardo Magalhães, Bahia, Brazil, respectively. The study evaluated different mechanical destruction equipment in combination with the chemical methods. In each environment, a randomized block experiment with four replications was employed. The results of the experiments indicated that the mechanical destruction increased the control efficiency by at least $10 \%$ when compared to chemical destruction of the cotton stalk. Chemical destruction with herbicides combined with mechanical destruction methods does not increase the control efficiency of cotton stalks destruction. Furthermore, the application of hormonal herbicides following the mechanical shredding of cotton stalks does not increase the control efficiency of glyphosate-resistant cotton stalk.
\end{abstract}

Keywords: phytosanitary break, agricultural machinery, regrowth, Gossypium hirsutum

\title{
1. Introduction
}

Cotton stalk destruction after harvest is a recommended prophylactic and crucial practice required in most Brazilian states where cotton is grown that is implemented as a phytosanitary break period. This practice aims to reduce pest populations, especially the boll weevil, Anthonomus grandis Boheman (coleoptera: Curculionidae), which is considered highly destructive to the crop, the pink caterpillar, Pectinophora gossypiella (Lepidoptera: Gelechidae), and the cotton root borer, Eutinobothrus brasiliensis (Coleoptera: curculionidae). The pests usually remain lodged in the cotton stalk or grow in germinated plants (Vieira et al., 1999; Lima et al., 2013; Grigolli et al., 2015). According to Soares et al., (1994), destroying the cotton stalk leads to more than $70 \%$ reduction of the insect population in reproductive dormancy, which in the absence of crop destruction would survive in the off-season period and, consequently, infest the cultivation early in the next harvest. This procedure also reduces 
the source of inoculum for diseases such as ramularia leaf blight (Ramulariopsis pseudoglycines and Ramulariopsis gossypii Sin: Ramularia areola), target spot (Corynespora cassiicola), ramulosis (Colletotrichum gossypii var. cephalosporioides), angular leaf spot (Xanthomonas citri pv. Malvacearum) and viruses such as the cotton blue disease (Cotton leafroll dwarf virus) and atypical virosis (Atypical Cotton leafroll dwarf virus) (Galbieri et al., 2017; Agrofloglio et al., 2016) that occur in the cotton crop and compromise the production and productivity (Silva et al., 2006).

The cotton stalks remained in the field are traditionally destroyed by either cultural, mechanical, chemical methods in isolation or in combination; currently the chemical method is the most commonly used. With an increase in the geographical cultivated area using transgenic cultivars that are resistant to full-action herbicides such as glyphosate (Roundup Ready Flex ${ }^{\circledR}$ and Glytol ${ }^{\circledR}$ cultivars), it has been challenging to use chemical destruction methods, especially where soil moisture conditions are unfavorable at the time of application (Ferreira et al., 2018).

Before the introduction of herbicide-resistant cotton cultivars, the cotton stalk remained in the field were usually destroyed using one or two applications of full-action herbicides, usually 2,4-D and glyphosate applied isolation or in combination (Yang et al., 2006; Greenberg et al., 2007; Ribeiro et al., 2015). If some plants regrew, they would be controlled by weed management operations in the pre-sowing period or the post-emergence period of the crop cultivated in succession which was commonly the glyphosate-resistant soybean. Currently, the cultivation of glyphosate-resistant soybean in succession to glyphosate-resistant cotton has resulted in the cotton sprouts appearance in the soybean cultivation, due to herbicide inefficiency. These sprouted cotton plants acts as a source of food and oviposition for insect pests populations. They also act as inoculum sources for cotton diseases, which in the next crop or in the adjacent cotton crops would cause early infestations and increases in production costs.

The vast majority of published works have evaluated the control efficiency of cotton stalks using either mechanical or chemical methods in isolation. However, cotton stalks from cotton glyphosate resistant-herbicide possibly require combined mechanical and chemical methods to increase the cotton stalks destruction efficiency. The present work set out to evaluate the efficiency of combining mechanical and chemical methods in the stalk destruction of glyphosate herbicide-resistant cotton.

\section{Materials and Methods}

Two experiments were carried out to evaluate the effect of combined chemical and mechanical destruction in controlling the glyphosate-resistant cotton stalk. The first was conducted in 2014 in Primavera do Leste, Mato Grosso, Brazil, geographic coordinates $15^{\circ}$ 34' 44" S and 54 22' 48" W. The second was done in 2015 in Luís Eduardo Magalhães, Bahia, Brazil, geographic coordinates $12^{\circ} 05^{\prime} 12^{\prime \prime} \mathrm{S}$ and $45^{\circ} 42^{\prime} 37^{\prime \prime} \mathrm{W}$.

The experimental areas were cultivated with transgenic glyphosate herbicide-resistant cotton varieties IMA 5675 B2RF (experiment 1) and BRS 368 RF (experiment 2). The soil in the 


\section{Macrothink

first experiment was classified as Red-Yellow Latosol, with $37.7 \%$ of clay, $11.6 \%$ of silt and $50.7 \%$ of sand; and the soil in the second experiment was classified as an Oxisol, with $16 \%$ of clay, $6 \%$ of silt and $78 \%$ of sand (EMBRAPA, 2018). The meteorological data during the experimental period were recorded and are presented in Figures 1 and 2, for Primavera do Leste, Mato Grosso, Brazil and Luís Eduardo Magalhães, Bahia, Brazil, respectively. Herein, we describe in detail the methodologies for each experiment.

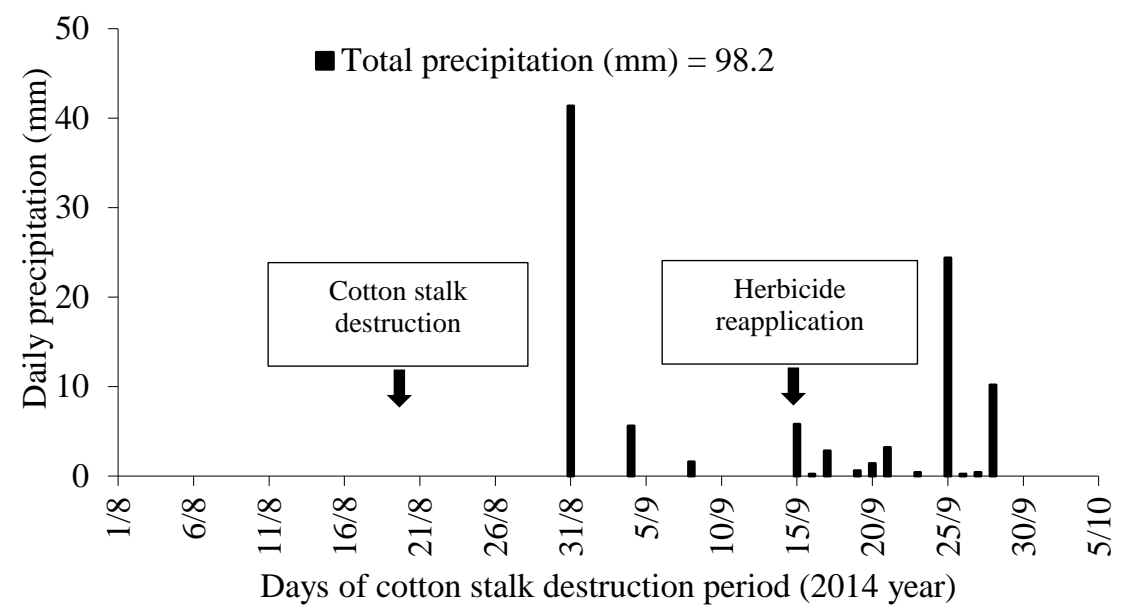

Figure 1. Precipitation during the conduction of the experiment in Primavera do Leste, Mato Grosso, Brazil

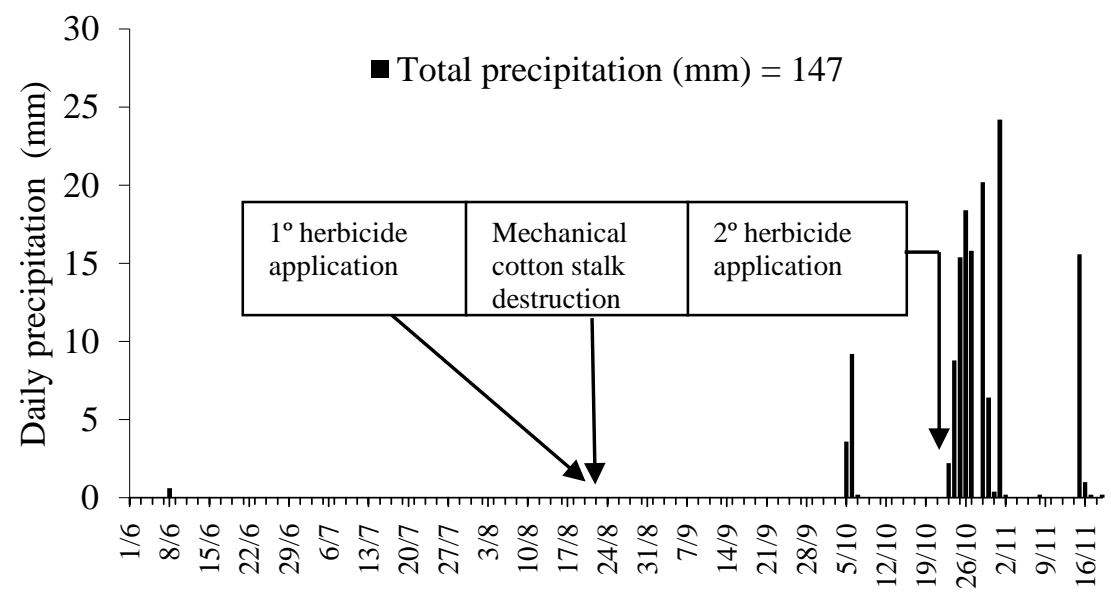

Days of cotton stalk destruction period (2015 year)

Figure 2. Precipitation during the conduction of the experiment in Luís Eduardo Magalhães, Bahia, Brazil 
2.1 Comparison of Mechanical and Chemical Methods Isolated or Combined for the Cotton Stalk Destruction

The experiment was implemented in an experimental area located in Primavera do Leste, Mato Grosso, Brazil shortly after the cotton harvest. The experimental units were delimited and the initial plant stand was determined by counting the number of plants present throughout the useful portion of the plot before shredding procedure performed in all the plants in the plots. The experimental units were composed of eight $40 \mathrm{~m}$ long cotton lines spaced $0.90 \mathrm{~m}$ apart. Four central lines of the experimental portion were selected for the evaluations, totaling a $144 \mathrm{~m}^{2}$ area as useful plot. The experiment was performed in a factorial combination with four methods of cotton stalk destruction (mechanical with stalk puller with discs in "V", mechanical with a plant cutter, chemical control with herbicides and mechanical with a plant puller) and the combination of the methods (without reapplication of herbicides - isolated methods and with reapplication of herbicides - combined methods), in addition to a control (performed only with cotton stalks shredding), in a randomized block design with four replications. In the chemical control, a mixture containing $1612 \mathrm{~g} \mathrm{ha}^{-1}$ of 2,4-D herbicide (1340 $\mathrm{g} \mathrm{ha}^{-1}$ acid equivalent) $+60 \mathrm{~g} \mathrm{ha}^{-1}$ of flumiclorac-penthyl herbicide was used; the applications were performed during the implementation of the experiment (chemical without reapplication of herbicides) and 25 days after first application, or after mechanical destruction (with herbicides reapplication - combined methods).

The characteristics of the mechanical equipment used in the experiment are described below:

Stalk puller with discs in "V" - This is an equipment that works by being coupled to the tractor's three-point hydraulic system. At the front of each line, there is a roller with knives for loosening the soil following which the plants are pulled out by double concave discs aligned in a "V" shape which act by pressing and pulling out the cotton stalk conducting thus the uprooting the plant. The discs have small fins screwed on their external side to facilitate their adherence to the ground and discs rotation to aide in cotton uprooting.

Concave disks convergent destroyer - This is an equipment that operates by being coupled to the tractor hydraulics. Its active organs are converging concave flat discs that act in misaligned pairs on the cotton row, at a depth of $8 \mathrm{~cm}$ to $15 \mathrm{~cm}$. The discs act below the soil surface and promote the removal of cotton stalk; however, small grooves are formed. The soil leveling is performed with small sections of leveling harrows, equipped with concave and toothed discs, located at the rear of the puller.

Flat disks cutter - Consisting in an equipment has that two flat discs for each cotton row whose synchronic rotation is caused by hydraulic motors. The discs are angled in relative to the ground to favor their penetration and maintain a uniform working depth varying from 3 to $5 \mathrm{~cm}$. The plants are cut close to the soil surface to prevent regrowth. The hydraulic motors are driven by a hydraulic system connected to the tractor's power take-off (PTO). For the flat disk cutter to work efficiently its two discs must be placed very close to each other; this can be performed by adjusting the equipment. 
2.2 Glyphosate-Resistant Cotton Stalk Control by Combining Mechanical and Chemical Methods

The experiment was implemented shortly after the cotton harvest of the 2014/2015 crop, in an experimental area located in Luís Eduardo Magalhães, Bahia, Brazil. Before beginning the cotton stalk destruction, the portions were delimited and the plant stand was assessed by counting all the plants present in the useful area of the experimental plot. The design used was a randomized block design with four replications. The experimental units were composed of eight $10 \mathrm{~m}$ cotton lines spaced $0.76 \mathrm{~m}$. The four central lines of the portion were selected for evaluation. Fifteen different combinations of methods of mechanical and/or chemical cotton stalk destruction were evaluated. The treatments were as follows: 1) shredding only (control treatment); 2) 2,4-D after shredding + 2,4-D after regrowth; 3) shredding + mechanical pulling out; 4) 2,4-D after shredding + 2,4-D after regrowth; 5) 2,4-D after shredding; 6) 2,4-D after shredding + mechanical pulling out; 7) 2,4-D after shredding + mechanical pulling out $+2,4$-D after regrowth; 8) 2,4-D + triclopyr after shredding $+2,4-\mathrm{D}$ after regrowth; 9) 2,4-D + triclopyr after shredding; 10) 2,4-D + triclopyr after shredding + mechanical pulling out; 11) 2,4-D + triclopyr after shredding + mechanical pulling out + 2,4-D after regrowth; 12) triclopyr after shredding + 2,4-D after regrowth; 13) triclopyr after shredding; 14) triclopyr after shredding + mechanical pulling out and 15) triclopyr after shredding + mechanical pulling out $+2,4-\mathrm{D}$ after regrowth.

The cotton stalk mechanical pull out was performed with a stalk puller with discs in "V". Chemical destruction was performed with herbicide application at doses of $1340 \mathrm{~g} \mathrm{ha}^{-1}$ of the acid equivalent (a.e.) of 2,4-D and/or $480 \mathrm{~g} \mathrm{ha}^{-1}$ a.e. of triclopyr, in the first application, and $1005 \mathrm{~g} \mathrm{ha}^{-1}$ a.e. of 2,4-D in the second application. The herbicide applications were performed immediately after shredding. A tank for herbicide storage with an electric pump was adapted onto the cotton stalk shredding machine. The herbicide spray was done using BD 11002 fan jet nozzle, coupled to a bar installed at the rear of the shredding machine, with a flow rate of $150 \mathrm{~L} \mathrm{ha}^{-1}$, with shredding followed by pulverization in a single operation. For the other chemical destruction procedures that were implemented later, the herbicides were applied with a bar sprayer at a flow rate of $150 \mathrm{~L} \mathrm{ha}^{-1}$.

In both mechanical and chemical destruction, the percentage of regrowth control was calculated by dividing the number of regrowth plants by the total number of plants obtained before the treatments were applied, multiplied by 100 . The number of regrowth plants was evaluated at 45 and 60 days after the beginning of the cotton stalk destruction in experiments 1 and 2 , respectively.

The data from both experiments were subjected to analysis of variance. For the first experiment, the Tukey test $(\mathrm{P} \leq 0.05)$ was applied in the factorial comparisons treatments while the Dunnet's test $(\mathrm{P} \leq 0.05)$ was applied to compare the control treatment (additional treatment) with the other treatments. In the second experiment, the means were grouped by the Scott-Knott (1974) test at 5\% of significance level. 


\section{Results and Discussion}

3.1 Comparison of Mechanical and Chemical Methods Isolated or Combined for the Cotton Stalk Destruction

The percentage of cotton stalk control varied based on the methods of destruction. The highest percentages of cotton regrowth control were obtained in mechanical destruction and the lowest in chemical destruction (Table 1). The mechanical cotton stalk destruction provided control of regrowth plants higher than $98 \%$ for all evaluated equipments. This cotton stalk destruction efficiency is similar to that obtained by Bianchini and Borges (2013). According to these authors, the most efficient equipment was the concave disks convergent destroyer and the flat disks cutter, whereas the least efficient was the disk harrow machine.

The chemical method control efficiency for the mixture containing the herbicides 2,4-D + flumichlorac-pentyl in a single application was lower than the mechanical method control and the chemical method with two herbicide applications (Table 1). In general, the chemical methods of cotton stalk destruction were less efficient than mechanical destruction methods, regardless of there was an herbicide mixture reapplication or not. The reapplication provided an increase in the control percentage from 78.4 to $89.4 \%$. The increase in stalk control efficiency is probably due to the precipitations that occurred before and after the second application of the herbicides (Figure 1). Similar results were obtained by Ferreira et al., (2018), who found that two herbicide 2,4-D applications enhanced cotton stalk control from 67 to $95 \%$, depending on the evaluated site. These authors attributed the variations in the efficiency of regrowth control to the difference in soil moisture in the locations evaluated. Despite the more favorable moisture conditions in the second application, the control efficiency was still less than $90 \%$, indicating the need for a new herbicide application to improve the cotton stalk control. However, this application that would occur during the phytosanitary break period, would delay the sowing of soybeans, a crop normally grown in succession to cotton in the Brazilian Cerrado cotton production areas. The cotton stalk should have regrowth and photosynthetically active structures, and the soil ought to have sufficient water to favor plant metabolism and consequently, the herbicide absorption and translocation for an efficient chemical destruction (Ferreira et al., 2018).

The least efficient mechanical control method was the one that used mechanical shredding only, which resulted in a $14.2 \%$ control (equivalent to $85.8 \%$ regrowth). Thus using this cotton stalk destruction method in isolation is not suitable. The mechanical cotton stalk destruction combined with chemical destruction, using the 2,4-D + flumichlorac-pentyl herbicides, did not significantly increase the control efficiency (Table 1).

The results obtained from this first experiment indicate that the cotton stalk destruction treatments with mechanical control showed the highest cotton stalk control efficiency (close to $100 \%$ ), which may favor the elimination of pest insects and plant pathogens propagules during the phytosanitary break period. The ideal cotton stalk destruction is that one in which $100 \%$ of the stalk is eliminated, which favors the control of insect pests and diseases, with an emphasis on the boll weevil that can survive in the off-season by feeding on these undestructed remaining plants (Azambuja and Degrande, 2014). 
Table 1. Regrowth control percentage in glyphosate-resistant transgenic cotton according to cotton stalk destruction method, at 45 days after the implementation of the experiment. Primavera do Leste, Mato Grosso, Brazil

\begin{tabular}{llc}
\hline \multirow{2}{*}{ Cotton stalk destruction method } & \multicolumn{2}{c}{ Control percentage (\%) } \\
\cline { 2 - 3 } & $\begin{array}{l}\text { Isolated } \\
\text { methods }\end{array}$ & $\begin{array}{l}\text { Combined } \\
\text { methods }\end{array}$ \\
\hline Mechanical - shredding + stalk puller with discs in "V" & $99.81 \mathrm{aA}$ (1) & $99.83 \mathrm{aA}$ \\
Mechanical - shredding + concave disks convergent destroyer & $98.10 \mathrm{aA}$ & $99.58 \mathrm{aA}$ \\
Chemical - shredding + herbicide (2,4-D + flumichlorac) & $78.36 \mathrm{bB}$ & $89.40 \mathrm{bA}$ \\
Mechanical - shredding + flat disks cutter & $99.97 \mathrm{aA}$ & $99.87 \mathrm{aA}$ \\
\hline Shredding only (control treatment) & \multicolumn{2}{c}{$14.22(2)$} \\
\hline CV $(\%)$ & \multicolumn{2}{c}{3.88} \\
\hline
\end{tabular}

${ }^{(1)}$ Means followed by the same lowercase letter in the column and uppercase letters in the line do not differ by Tukey's test $(\mathrm{P} \leq 0.05)$.

(2) Dunnet's test $(\mathrm{P} \leq 0.05)$ was used to compare the control treatment with the other treatments.

\subsection{Glyphosate-Resistant Cotton Stalk Control by Combining Mechanical and Chemical Methods}

The control percentage of glyphosate-resistant cotton stalk varied significantly between treatments (Table 2). The highest cotton stalk control efficiencies occurred in treatments combining the chemical and mechanical method and the treatment using the mechanical method only. The lowest control efficiencies occurred in the shredding (control treatment) and in the treatments sprayed with herbicides once (after shredding) and twice (after shredding and after regrowth). In the treatment in which two herbicide 2,4-D applications were performed after regrowth, the control efficiency was also very low (13\%), showing to be similar to that obtained in the control treatment in which only the shredding was carried out. This lower control efficiency in the treatments sprayed with herbicide can be attributed to the absence of precipitations during the execution of the experiment (Figure 2), which probably reduced the soil moisture in an area where the soil is composed of $78 \%$ sand and $16 \%$ clay hindering the action of herbicides. According to Crafts (1956), 2,4-D is a systemic herbicide translocated by the plants xylem and phloem. Its translocation is reduced when the soil contains low moisture resulting in low accumulation of the herbicidal molecule in the apical meristem tissues and in the roots where the herbicide operates. 
Table 2. Regrowth control percentage in glyphosate-resistant transgenic cotton according to cotton stalk destruction method, 60 days after the implementation of the experiment. Luís Eduardo Magalhães, Bahia, Brazil

\begin{tabular}{|c|c|c|c|c|}
\hline Trat. & ${\text { chemical - } 1^{\mathrm{a}} \text { application }}^{1}$ & $\begin{array}{l}\text { Mechanical } \\
\text { pulling out }^{2}\end{array}$ & $\begin{array}{c}\text { chemical - } \\
2^{\mathrm{a}} \text { application }^{3}\end{array}$ & $\begin{array}{c}\text { Control } \\
(\%)\end{array}$ \\
\hline 01 & - & - & - & $10.1 \mathrm{c}^{4}$ \\
\hline 02 & $2,4-\mathrm{D}$ in regrowth & - & 2,4-D after regrowth & $13.0 \mathrm{c}$ \\
\hline 03 & - & yes & - & $98.8 \mathrm{a}$ \\
\hline 04 & 2,4-D after shredding & - & 2,4-D after regrowth & $24.3 \mathrm{~b}$ \\
\hline 05 & 2,4-D after shredding & - & - & $11.8 \mathrm{c}$ \\
\hline 06 & 2,4-D after shredding & yes & - & $99.7 \mathrm{a}$ \\
\hline 07 & 2,4-D after shredding & yes & 2,4-D after regrowth & $99.8 \mathrm{a}$ \\
\hline 08 & $2,4-\mathrm{D}+$ triclopyr after shredding & - & 2,4-D after regrowth & $11.2 \mathrm{c}$ \\
\hline 09 & $2,4-\mathrm{D}+$ triclopyr after shredding & - & - & $8.6 \mathrm{c}$ \\
\hline 10 & $2,4-\mathrm{D}+$ triclopyr after shredding & yes & - & $99.4 \mathrm{a}$ \\
\hline 11 & 2,4-D + triclopyr after shredding & yes & 2,4-D after regrowth & $99.9 \mathrm{a}$ \\
\hline 12 & Triclopyr after shredding & - & 2,4-D after regrowth & $19.0 \mathrm{~b}$ \\
\hline 13 & Triclopyr after shredding & - & - & $18.7 \mathrm{~b}$ \\
\hline 14 & Triclopyr after shredding & yes & - & $99.3 \mathrm{a}$ \\
\hline 15 & Triclopyr after shredding & yes & $2,4-\mathrm{D}$ after regrowth & $99.1 \mathrm{a}$ \\
\hline \multicolumn{4}{|c|}{$\mathrm{CV}(\%)$} & 12.0 \\
\hline
\end{tabular}

${ }^{1}$ In the chemical control in the first application, doses of $1340 \mathrm{~g} \mathrm{ha}^{-1}$ of a.e. of 2,4-D and/or $480 \mathrm{~g} \mathrm{ha}^{-1}$ of a.e. of triclopyr were used, depending on the treatment.

${ }^{2}$ For mechanical control, the stalk puller with discs in "V" was used 7 days after shredding and, depending on the treatment, application of the herbicides.

${ }^{3}$ In the chemical control with the second herbicide application (after regrowth), a dose of $1005 \mathrm{~g} \mathrm{ha}^{-1}$ of a.e. of 2,4-D was used.

${ }^{4}$ Means grouped by the same letter do not differ by the Scott-Knott test $(\mathrm{P} \leq 0.05)$.

The mechanical cotton stalk destruction with the stalk puller with discs in "V" provided 98.8\% control. The combination of mechanical and chemical destruction at the time of shredding did not differ significantly from the treatments that used mechanical destruction only. When mechanical destruction was combined with chemical destruction with two herbicide applications, one after shredding and the other when the plants showed regrowth, the control of cotton stalk for the treatment with applications of 2,4-D and 2,4-D + triclopyr when shredding was $99.8 \%$ and $99.9 \%$, respectively. Nevertheless, these two treatments that showed numerically the highest percentage of cotton stalk control, did not differ significantly from the other treatments using mechanical destruction. It is possible that the two hormonal herbicide applications helped in the plants control, that were not efficiently pulled out by 
mechanical destruction. Based on these results, the use of the herbicide triclopyr in isolation or in a mixture containing 2,4-D that has a high cost and control efficiency similar to the herbicide 2,4-D, is not advantageous. Similar results were illustrated by Andrade Júnior et al. (2016), who were unable to show an increase in control efficiency using the mixture of herbicides 2,4-D and triclopyr when compared to the application of 2,4-D in isolation.

Only the results obtained with use of the shredding machine followed by operation with the stalk puller with discs in "V" was sufficient to control $98.8 \%$ of the cotton stalk. There are no significant differences between isolated mechanical destruction methods and combined mechanical and chemical destruction methods with two herbicide applications. However, it is noteworthy that plants that are not uprooted using equipment at the time of cotton stalks destruction normally regrowth when soil moisture is restored at the beginning of the rainy season and in the absence of herbicide intoxication, they generate vigorous vegetative and reproductive structures.

In general, the results obtained in this study indicate that shredding combined with the using of equipment developed specifically for the cotton stalk control is more efficient than the shredding combined with chemical method using herbicides. It was evident that the low soil moisture content during periods of no precipitations reduced the chemical control efficiency of cotton stalk destruction, since the herbicides need the plant to be in full development and in the absence of hydric stress for efficient regrowth control. However, the few remaining plants that are not pulled out by the mechanical method, can regrowth and develop vegetative and/or reproductive structures in the absence of herbicide treatment. Thus, the combined use of mechanical and chemical methods can minimize the remaining plants regrowth and prevent the multiplication of pest insects and plant pathogens.

\section{Conclusions}

The mechanical method is the most efficient for cotton stalk destruction; Chemical destruction combined with mechanical destruction does not increase the control efficiency of cotton stalk destruction; The application of hormonal herbicides following by the stalk shredding does not increase the control efficiency of the glyphosate-resistant cotton stalk.

\section{References}

Agrofoglio, Y. C., Delfosse, V. C., Casse, M. F., Hopp, H. E., Kresic, I. B., \& Distéfano, A. J. (2016). Identification of a new cotton disease caused by an atypical cotton leafroll dwarf virus in Argentina. Phytopathology, 107, 369-376.

https://doi.org/10.1094/PHYTO-09-16-0349-R

Andrade Junior, E. R., Cavenaghi, A. L., \& Guimarães, S. C. (2017). Destruição química de soqueira em variedades de algodoeiro resistentes ao glifosato - Safra 2016. Cuiabá: IMAmt. (Instituto Matogrossense do Algodão. Circular Técnica, 29).

Azambuja, R., \& Degrande, P. E. \& Trinta anos de bicudo-do-algodoeiro no Brasil. (2014). Arquivos do Instituto biológico, 81, 377-410. https://doi.org/10.1590/1808-1657000012013

Bianchini, A., \& Borges, P. H. M. (2013). Evaluation of cotton stalks destroyers. Engenharia 
Agrícola, 33, 965-975. https://doi.org/10.1590/S0100-69162013000500008

Crafts, A. S. I. (1956). The mechanism of translocation: methods of study with $\mathrm{C}^{14}$-labeled 2,4-D. Hilgardia, 26, 287-334. https://doi.org/10.3733/hilg.v26n06p287

EMBRAPA - Empresa Brasileira de Pesquisa Agropecuária. Sistema Brasileiro de Classificação de Solos. 5. Ed. Rio de Janeiro: Embrapa Solos, 2018. 355p.

Ferreira, A. C. B., Bogiani, J. C., Sofiatti, V., \& Silva Filho, J. L. (2018). Chemical control of stalk regrowth in glyphosate-resistant transgenic cotton. Revista Brasileira de Engenharia Agrícola e Ambiental, 22(08), 530-534.

https://doi.org/10.1590/1807-1929/agriambi.v22n8p530-534

Francischini, A. C., Constantin, J., Matte, W. D., Oliveira Junior, R. S., Rios, F. A., \& Machado, F. G. (2019). Association of mechanical and chemical methods for cotton stalk destruction. Planta Daninha, 37, e019207486.

https://doi.org/10.1590/S0100-83582019370100141

Galbieri, R., Boldt, A. S., Scoz, L. B., Rodrigues, S. M., Rabel, D. O., Belot, J. L., ... \& Chitarra, L. G. (2017). Cotton blue disease in central-west Brazil: Occurrence, vector (Aphis gossypii) control levels and cultivar reaction. Tropical Plant Pathology, 42(6), 468-474. https://doi.org/10.1007/s40858-017-0165-1

Greenberg, S. M, Sparks Jr., A. N., Norman Jr., J. W., Coleman, R., Bradford, J. M., Yang, C., Sappington, T. W., \& Showler, A. (2007). Chemical cotton stalk destruction for maintenance of host-free periods for the control of overwintering boll weevil in tropical and subtropical climates. Pest Managment Science, 63, 372-380. https://doi.org/10.1002/ps.1348

Grigolli, J. F. J., Crosariol Netto, J., Izeppi, T. S., Souza, 1. A., Fraga, D. F., \& Busoli, A. C. (2015). Infestação de Anthonomus grandis (Coleoptera: Curculionidae) em rebrota de algodoeiro. Pesquisa Agropecuária Tropical, 45, 200-208.

https://doi.org/10.1590/1983-40632015v4532296

Lima, I. S. J., Degrande, P. E., Miranda, J. E., \& Santos, W. J. (2013). Evaluation of the boll weevil Anthonomus grandis Boheman (Coleoptera: Curculionidae) suppression program in the state of Goiás. Brazilian Neotropical Entomology, 42, 82-88.

https://doi.org/10.1007/s13744-012-0083-3

Ribeiro, E. B., Castellani, M. A., Silva, C. A. D., Melo, T. L., Silva, G. S., Vale, W. S., \& Santos, A. S. (2015). Methods of cotton stalk destruction and survival of boll weevil. Pesquisa Agropecuária Brasileira, 50, 993-998.

https://doi.org/10.1590/S0100-204X2015001100001

Scott, A., \& Knott, M. (1974). Cluster-analysis method for grouping means in analysis of variance. Biometrics, Washington D.C., 30(3), 507-512. https://doi.org/10.2307/2529204

Silva, O. R. R. F., Ferreira, A. C. B., Lamas, F. M., Fonseca, R. G., \& Beltrão, N. E. M. Destruição dos restos culturais, colheita e beneficiamento do algodoeiro. Campina Grande: Embrapa Algodão, 2006. (Embrapa Algodão. Circular Técnica, 99). 


\section{Macrothink

Soares, J. J., Busoli, A. C., Yamamoto, P. T., \& Braga Sobrinho, R. (1994). Efeito de práticas culturais de pós-colheita sobre populações do bicudo-do-algodoeiro, Anthonomus grandis Boheman, 1843. Pesquisa Agropecuária Brasileira, Brasília, D.F., 29(3), 375-379.

Vieira, D. J., Nóbrega, 1. B., Azevêdo, D. M. P., Beltrão, N. E. M., \& Silva, O. R. R. F. (1999). Destruição dos restos culturais. In: Beltrão, N. E. de M. (Coord.). O Agronegócio do Algodão no Brasil. Brasília, D.F.: Embrapa Comunicação para Transferência de Tecnologia, 2, 603-615.

Yang, C., Greenberg, S. M., Everit, J. H., \& Normam Junior, J. W. (2006). Assessing cotton stalk destruction whit herbicides using remote sensing technology. Journal of Cotton Science, 10, 136-145.

\section{Copyright Disclaimer}

Copyright for this article is retained by the author(s), with first publication rights granted to the journal.

This is an open-access article distributed under the terms and conditions of the Creative Commons Attribution license (http://creativecommons.org/licenses/by/4.0/). 